\title{
Helyreigazítás a Megtakarítás és adózás egy önkéntes nyugdíjrendszerben - az ágensalapú modellezés felé címü cikkhez
}

A Közgazdasági Szemle 2016. évi májusi számában megjelent cikkünkben az önkéntes nyugdíjrendszert analitikus és ágensalapú módszerrel elemeztük. Az angol változat egyik névtelen bírálója észrevette, hogy a 482. oldalon lévő (8) és a (13) utáni számozatlan képletben hibásan modelleztük az önkéntes megtakarítások állami támogatását. Ebben a helyreigazításban kijavítjuk a hibát, és megadjuk az érintett 4-6. táblázatokból legalább a 4. táblázat helyes változatát (vö. 486. o.).

A felhalmozott megtakarítás támogatassál:

$S_{a, i, t+i}=S_{a-1, i, t+i-1}+(1+\alpha) s_{a, i, t+i}, \quad t=0,1,2, \ldots$,

ahol $a$ az életkor, $i$ a típus indexe, $t$ a naptári idő indexe, $s$ és $S$ a megfelelő időszakban megtakarított, illetve az időszak végére felhalmozott megtakarítás, $\alpha$ pedig a támogatási arány.

A magán-életjáradék a nyugdíjazásig felhalmozott megtakarítás és a hátralévő élettartam hányadosa a (13) alatti számozatlan képletben:

$d_{i, t+R}=\psi S_{R, i, t+R}$

[Az eredeti változat (8) képletében nem vettük figyelembe, hogy a kiegészítés csak a támogatási rendszer életbe lépésekor jelenik meg, és egyszerúsítésként csak a (13) utáni számozatlan képletben jelentettük meg, ezáltal hibásan kiterjesztve a támogatást a támogatás előtti időszakokra is.]

A 4. táblázatot (486. o.) újraszámolva, adódik az új táblázat. Az eltérés csak kvantitatív, de nem elhanyagolható.

* Király Balázs-Simonovits András [2016]: Megtakarítás és adózás egy önkéntes nyugdíjrendszerben - ágensalapú modellezés. Közgazdasági Szemle, 63. évf. 5. sz. 473-500. o. http://dx.doi. org/10.18414/KSZ.2016.5.473. 
4. táblázat

Makrojellemzők és előrelátó megtakarítások

\begin{tabular}{|c|c|c|c|c|c|c|c|c|}
\hline \multirow{3}{*}{$\begin{array}{l}\text { Évtized } \\
\mathbf{t}\end{array}$} & \multirow{3}{*}{$\begin{array}{l}\text { Adósság } \\
\mathcal{D}_{\mathrm{t}}\end{array}$} & \multirow{3}{*}{$\begin{array}{c}\text { Adókulcs } \\
\theta_{\mathbf{t}}\end{array}$} & Belső & Külső & \multicolumn{4}{|c|}{ Előrelátó dolgozók megtakarítása } \\
\hline & & & \multicolumn{2}{|c|}{ szórás } & legfiatalabb & fiatal & idős & legidősebb \\
\hline & & & $\varepsilon_{I, \mathbf{t}}$ & $\varepsilon_{E, \mathbf{t}}$ & $s_{1, H, \mathbf{t}}$ & $s_{2, H, \mathbf{t}}$ & $s_{3, H, \mathbf{t}}$ & $s_{4, H, \mathbf{t}}$ \\
\hline $\mathbf{0}$ & 0,088 & 0,000 & 0,232 & 0,013 & 0,080 & 0,083 & 0,089 & 0,100 \\
\hline 1 & 0,109 & 0,022 & 0,212 & 0,025 & 0,076 & 0,074 & 0,076 & 0,078 \\
\hline 2 & 0,118 & 0,027 & 0,201 & 0,020 & 0,075 & 0,074 & 0,077 & 0,082 \\
\hline 3 & 0,120 & 0,029 & 0,191 & 0,019 & 0,074 & 0,074 & 0,077 & 0,080 \\
\hline 4 & 0,121 & 0,030 & 0,182 & 0,017 & 0,074 & 0,074 & 0,076 & 0,080 \\
\hline 5 & 0,122 & 0,030 & 0,173 & 0,015 & 0,074 & 0,074 & 0,076 & 0,080 \\
\hline 6 & 0,122 & 0,030 & 0,171 & 0,014 & 0,074 & 0,074 & 0,076 & 0,080 \\
\hline
\end{tabular}

Az olvasóktól elnézést kérünk!

Király Balázs-Simonovits András 